International Journal of Instruction

e-ISSN: 1308-1470 • www.e-iji.net
July $2017 \bullet$ Vol.10, No.3

p-ISSN: 1694-609X

pp. $159-176$

Received: 19/02/2017

Revision: 26/04/2017

Accepted: 30/04/2017

\title{
Teaching English to a Student with Autism Spectrum Disorder in Regular Classroom in Indonesia
}

\author{
Ni Nyoman Padmadewi \\ Prof., Ganesha University of Education, Indonesia, \\ padmadewi@northbalibilingualschool.org
}

\section{Luh Putu Artini}

Ganesha University of Education, Indonesia, putu.artini@undiksha.ac.id

The recognition of students with special needs has been increasing significantly in Indonesia recently and the better understanding as well as supportive school programs is urgently needed. It was found out that schools and teachers in Indonesia had very limited preparedness either in teaching skills or material development to meet the actual needs of the students. This study then aimed at investigating appropriate strategies of teaching English to a student with Autistic Spectrum Disorder (ASD) included in a regular classroom. This research was in the form of a case study conducted in North Bali Bilingual School. The data were collected through observations and interviews. The findings show that the Individual Education Plan (IEP) provided with visual media through co-teaching, differentiated instruction and also through a "buddy program" are found appropriate to help the student learn English as a foreign language. These strategies are effective to be implemented in an inclusive classroom program.

Keywords: autism spectrum disorder, inclusive school, regular classroom, student with special needs, teaching English

\section{INTRODUCTION}

It cannot be denied that education plays an important role in the life of every individual, therefore equality and equity in education needs to be strengthened and supported to confirm the need of giving care and attention to all including the students with special needs. Having basic education is the right of every individual in Indonesia, and the treatment toward special need children which has been commonly carried out in Bali to segregate them from other students who are in a regular classroom, and treat them differently from the mainstream students. One type of special need students is the student with Autism Spectrum Disorder (hereafter, ASD) which increases in its

Citation: Padmadewi, N. N. \& Artini, L. P. (2017). Teaching English to a Student with Autism Spectrum Disorder in Regular Classroom in Indonesia. International Journal of Instruction, 10(3), 159-176. https://doi.org/10.12973/iji.2017.10311a 
prevalence in United States (Pearson, 2015), and also observed to be increasing in Indonesia as reported by the principal and the teachers at inclusive schools in Bali.

The segregation of the special needs students in North Bali and also other places in Bali has been conducted by the government in a special government school for special need children called "Sekolah Luar Biasa (hereafter, SLB"), and this type of education has been well accepted in society and so far been considered as the best treatment for the students. SLB is the specialist school for students who have learning difficulties which includes the students who are physically disabled and behaviourally and emotionally disturbed. However there have been an increasing number of parents who prefer to enrol their children at a regular school as they want their children to be educated in a regular classroom like other mainstream students. In spite of the preference of the parents, it cannot be denied that the segregation of the special need children may prove to be easier for the teacher because pedagogically the teacher might find it easier to handle the students having similar conditions in a classroom. However experts and researchers who work in special education question the benefits of segregated special education and consider that integrating them in a regular classroom may bring better results. Rutte (2014) stated that integrating special need students in a regular classroom is rooted from several reasons. The special need teachers and students feel that they have been excluded and hidden away in their schools, even the best equipped school cannot replace the normal environment. Integrating students is also considered to be more attractive to parents. The development of character values like tolerance, empathy, and helpfulness is often not a priority in mainstream schools and a policy of integration could help improve this. Inclusion is also pertaining to equity and social justice which show acceptance, and practice respect, empathy, care and recognition (Frattura \& Capper, 2007; Theoharries, 2009; and Ford, 2013). This article is intended to describe how the student of ASD is taught and treated in the classroom and what strategies are used to teach the student.

\section{Inclusion and ASD Student}

Inclusion can be described as the practice of including students with disabilities alongside with other students in a regular classroom (Gilhool, 1989; Ford, 2013). Inclusion can be described as including students of different conditions, backgrounds and abilities to be in the same classroom. Theoretically, inclusion is related to philosophical decision that emphasizes 'the importance of bringing together diverse students, families, educators and community members', in the purpose of establishing supportive learning atmosphere that helps every individual student the feeling of respect, acceptance and the sense of belonging. Inclusive education recognizes that all students are learners who benefit from a challenging, meaningful, appropriate curriculum (Meynert, 2014).

Special need students frequently discovered in a regular classroom are diagnosed Autism Spectrum Disorders (ASD). ASD students clearly require special attention and care. Autism is stated as having impairments in reciprocal social communication and social interaction, and the presence of restricted and repetitive behaviors, interests, or activities (American Psychiatric Association, 2013; Tuononen, Laitila, \& Kärnä, 2014; 
British Columbia Ministry of Education, 2000); McCorkle, 2012). The student with Autism Spectrum Disorder (ASD) is less likely than his normal peers to initiate conversations, respond appropriately to the conversational turns and be able to understand the intention and the illocutionary force of utterances. He also shows poor understanding towards the emotional states of others and struggle in particular to use facial expressions to show his emotions (Cummings, 2014). The children with autism struggle with comprehension (Williamson, et al., 2014; Accardo, 2015). Besides that, students with disabilities often have problem with managing their cognitions in order to understand what they read (Cain et al, 2004; Duff \& Clarke, 2015). Research proved that students with ASD may show ability in decoding any information but often have problem in comprehending what they read, and have difficulties in making inferences from texts (Nation et.al, 2006; Finnegan \& Mazin, 2015; Ricketts, 2011; Accardo, 2015). However blending normal, mildly and severely challenged students in the same class is not an easy job because the students who are severely challenged could experience a sense of failure if they are expected to follow the curriculum for normal children because they are unable to cope.

\section{Strategies for Handling Students with Learning Disabilities}

Four strategies that can be recommended for handling students with learning disabilities including ASD are: co-teaching, differentiated instruction, and peer-mediated instruction and interventions (Ford, 2013). Vaughn, Schumm, \& Arguelles (1997) describe coteaching as a strategy of teaching where one teacher can function as the main teacher who is responsible for all instructions conducted in the classroom, who is assisted by another teacher who gives additional assistance. The next type of model is parallel teaching where the two teachers plan and design the lessons together before the class is split into 2 groups each of which is handled by each teacher. The benefit of this model is that each group can get each other's expertise in addition to being able to have discussion and work in small groups. The other model of co-teaching is a model where one teacher is responsible to prepare the main teaching and to do re-teaching if it is needed to provide additional support for students with learning disabilities. Beside these models, the two teachers can be in the same classroom each of which can take turns to do instructions for the students, or each can assist students while the other gives instructions for other students. The strategies implemented are mediated by the use of two languages (English and Bahasa Indonesia) to meet the mission of the school as a bilingual school. English is used fully by the main teacher who is a native speaker, and if found confusing, the assistant teacher / the shadow teacher can use Bahasa Indonesia to the student knowledge to clarify the meaning.

The students with ASD are special and the uniqueness requires explicit need for teachers to identify individualized approaches to help them achieve their academic goals (Mayton, et al., 2010; Accardo, 2015). An individualized strategy for ASD students can be in the form of differentiated instruction. Differentiated instruction is the instruction provided to students based on the different needs of the students in the same classroom (Choate 1993; Nordlund, 2003). 
Implementing a differentiating classroom is challenging and not an easy way to do (Padmadewi, 2013a). Tomlinson (1999, 2001) offers the three methods of differentiating instruction for any curricular area such as modifying the content, the process of learning, and the end product. Despite its complexity and high demand of commitment, the use of differentiated instruction reaches its most effective treatment especially in dealing with all students in inclusive classroom. The benefit of the differentiated instruction is therefore being able to provide learning opportunities to all students within an inclusive classroom (Ford, 2013).

Peer-mediated instruction and interventions are a set of alternative teaching strategies that employ the use of students as instructors for students in their class. The assignment of students in peer-mediated instruction change the role of the teacher from being the primary provider of instruction to that of a facilitator of peer provided instruction (Ford, 2013). The peer can provide instruction directly (through peer teaching or tutoring) or indirectly through modelling either about academic matters or dealing with social functions (Kalfus, 1984; Ford, 2013). For maximum results, visual media can be added to help the ASD students to conceptualize the abstract meaning through seeing it. The media can form concepts in the brain of the ASD student which leads him to understand better.

Referring to the information above, the purpose of this paper is therefore to describe how the English teacher teaches an ASD student included in the classroom and what strategies are implemented to teach English as a foreign language in an inclusive classroom.

\section{METHOD}

The design of the research was in the form of a case study which aimed at gaining 'indepth understanding of the situation and the meaning of the findings in real life (see for example, Diaz et al., 2013). The choice of the case study was based on the fact that inclusion classroom for ASD student was not easily found, and North Bali Bilingual School was one of the limited numbers of the schools that provided inclusive program for special need students. The study took place in a grade 3 classroom where a student had been diagnosed as having ASD. The student was about 10 years old and included in a normal classroom of 20 students. He understands enough basic vocabularies because of having English class with individual education plan since he was 6 years old. To guarantee the validity and reliability of the data, the triangulation techniques were implemented by confirming the result of observations through interview and analysing school documents. Data collection was conducted through non-participatory observation, for 10 hours a week in one full semester (6 months). In addition, data sources included the results of language receptive skill assessments, and interview with the shadow teacher and the school principal. The collected data were then analysed qualitatively and descriptively presented. Quantitative calculations were added when the frequency of behaviour needs to be counted. 


\section{FINDINGS}

The finding of the research shows that the concept of inclusion held in North Bali Bilingual School (NBBS) is not only pertaining to the notions of integration which entails the concerns of students with special education needs in order to help them establish their independency, but also implies the respect for the students' social, civil, and educational rights. Despite students' differences being taken into consideration, NBBS is not a fully inclusive school by design in certain cases. In practice, the implementation of inclusive education involves the inclusion of an ASD student and other students with mild special needs. The system of inclusion is adapted based on the condition of the students in particular the ASD student. Being low functioning in his social awareness and having deficits in interactions makes it hardly possible for the ASD student to be fully included in the classroom. Despite its difficulties, the practice of inclusion was found to have greater success at the elementary level compared to the secondary level (Ford, 2013).

The student was included in the classroom and sat at one of the chair provided and accompanied by the shadow teacher. The ASD student listened to the explanation of the English teacher and if he looked confused, the teacher then showed visual media. The shadow teacher always attempted to provide additional explanation (sometimes in the student's language if the concept is not understood. When the ASD student looked restless, the shadow teacher had to take him out and walked to another room and had a small game for variation. This pull-out system of teaching was designed using differentiated instruction.

One of the areas of use of differentiated instruction was to design a special Individual Education Plan (IEP) for the autistic child. One characteristic recognized on the student under study was the tendency to be visual learners. This is in line with McCorkle (2012) who states "because many students with ASD are described as visual learners, they tend to show improved response to information presented visually. By using a student's visual processing strength, these strategies can help decrease reliance on

areas of deficits, such as auditory processing and communication. The use of visual methods in teaching and learning can create longer lasting experiences and connect it to other sensory experiences (Wamalwa \& Wamalwa, 2014).

In order to suit the needs of the autistic student who tends to be a visual learner and matches with the situation of the accommodating classroom, the IEP needs visual media developed to suit the goal of the IEP and adapted based on the condition of the student. The information below explains how visual media were used in differentiated instruction for teaching English.

\section{Techniques of Teaching Using Differentiated Instruction Provided with Visual Media}

The ASD child is unique and special. Physically, he does not show any impairment, but socially he has difficulties. In communication with other persons, the student can express themselves in many ways, however most frequently has difficulties in seeking 
and maintaining eye contact, rarely look at other persons when socially interacting with others. The joint attention is expressed through the use of eye-gaze (Noris, et al., 2012; Tuononen, Laitila, and Kärnä, 2014). When the teacher taught about colours for example, the shadow teacher showed him many kinds of media (papers of different colours). The teacher picked one paper and mentioned the colour and asked him to repeat. To confirm his understanding the teacher partnered him with other student and have small exchange talk about colour. On vocabulary level, the ASD students can say all the colours in English but he did not have any understanding how it is used for communications.

Pearson (2015) and Meynert (2014) suggested that special education operates more as a mechanism of differentiation and less as a resource directed to pupils experiencing severe difficulties, and should work inclusively and therefore not be regarded as a system apart from regular education but part of normal educational practice. In line with that point of view aforementioned, the system developed for the integration of the ASD child in the regular classroom is considered as a part of the regular system based on the vision and mission of NBBS to respect diversity.

As a part of regular system, the ASD student is also exposed to the bilingual system of the school which uses Bahasa Indonesia (the national language of the country) and English. English is not only the patrimony of the Anglo Saxon but also a global language (Liton, 2012). As a global language, English is chosen as another medium of instruction in NBBS. The exposure of bilingual environment makes the student acquire the two languages naturally with no social and personal barrier which promotes the process of language learning.

Along with the process and the commitment of providing serious and professional helps for the student, special attention on how the special IEP should be developed in order to link and match with the needs and condition of the ASD student. Based on the observation conducted during the process of the treatment, the ASD student showed a quick understanding for things presented visually and amazingly had an ability to copy perfectly things he saw visually. He could response to questions in English prompted using pictures and very easily captured the objects visually. However, taking initiatives to do conversations either in English or his native language hardly occurred.

As put forward by Hodgdon (2006), there are two reasons why students with autism function better visually. First, they experience difficulty in smoothly and accurately controlling the shifting and re-establishing of attention. The problem is caused by cerebellar deficiencies that affect their ability to modulate sensory input. The nervous system of autistic students does not have the capacity to perform the function of social interaction which requires very rapid selection, prioritizing, and processing, of information. The resulting inability produces in part the early aloof and non-engaged behaviours and the auditory inconsistencies. Secondly, autistic students face difficulty attending to foreground sounds (communication message) and blocking out background noises (door closing, paper shuffling and other sounds from the environment). The normal listener is able to focus his attention selectively on the communication message while blocking out the background noise. Hodgdon found that the normal 
communication message can be described as 55\% visual (gestures, facial expressions, body movements, objects in the environment), $37 \%$ vocal (vocal intonation, rate and intensity or volume) and $7 \%$ verbal message (the actual words spoken). Accordingly, if the autistic students understand auditory information even less than normal listeners, it can be considered that only a small part of verbal language may actually be in their comprehension of communication.

In accordance with the vision of NBBS to respect diversity, giving access for the ASD student to register and have equal opportunities to have education in the school is one of their missions. For that reason, the student with ASD is provided with special treatment by the committed school management and teacher. The teacher has gone through special professional development trainings to understand how the treatment must best suit the student's need and at the same time meets the needs of the rest of the class members. The special treatment is in line with Hodgdon's three appropriate and realistic goals for special need students: (1) to teach skills, (2) to teach compensatory strategies, and (3) to modify environment for maximum learning. In order to establish the goals mentioned, the student was treated using the IEP, and taught using differentiated instruction. Differentiated instruction has been applied as the key philosophy of teaching in NBBS and found to be mostly effective in teaching special need students in an inclusive classroom (Padmadewi, 2013b). The use of differentiated instruction as a teaching strategy is intended to help students to have optimum progress based on their individual needs (Choate 1993). The implementation of differentiated instruction can certainly help students from different background to develop their full potential in the same classroom (Nordlund , 2003). The techniques and strategies of integrating special needs student in NBBS have therefore been conducted by implementing the IEP based on the combined concepts of differentiated instruction which has been carried out using two systems such as: 'pull out' and integrated system, with the Applied Behaviour Analysis of Handojo's Lovaas Method (Handojo, 2009). The pull-out and integrated system are utilized for best access of learning and to develop his maximum potential yet still enjoy the comfort zone created by the teacher. The shadow teacher provided in the classroom can also be an assistant for the main teacher.

The pull-out system is carried out if the ASD student requires 'his time'. The system can be done spontaneously to response to the student's need and condition. However, the pull-out system can be designed on purpose and based on an arranged schedule as a part of the IEP. This pull-out system is usually administered based on the topics taught and activities planned for the student. When the ASD student was pulled out, he studied in a special room different from the regular mainstream for which the media discussed above were utilized. The types of media used depended on the topics and the material being taught. The media for shaping for example can be in the forms of pictures or even the real objects to tell about kinds of nouns in English. By showing the media and saying it out, the shadow teacher was transferring the information which was understood through the visual image formed in the brain of the student. In order to make the understanding firm, the concept stored in the brain needs to be repeated, and the stimulus using the media could be then slowly decreased and eliminated if the understanding had been permanently stored in the student's brain. Specific to comprehension, research suggests 
that cooperative learning, anaphoric cueing, and one-to-one direct instruction are promising interventions to facilitate reading comprehension improvement in students with ASD (Accardo, 2015).

To respond to the need of the student toward visual stimulus, some media had been designed and developed in accordance with the types of elements provided in the IEP with one-to-one direct instruction. The term 'visual' included anything the student sees which can be objects, printed matter of any kind, body language and behaviour of others which become visual supports for communications. The kinds of visual media produced and utilized can be listed as follows.

\section{Media for Discrete Trial Training (DTT)}

Discrete Trial Training (DTT) is one of the main techniques of the ABA method (Handojo, 2009) which becomes the main strategy used in handling the special needs student in NBBS. DTT was done in several cycles each of which consists of giving instruction, prompting and ended with giving a reward.

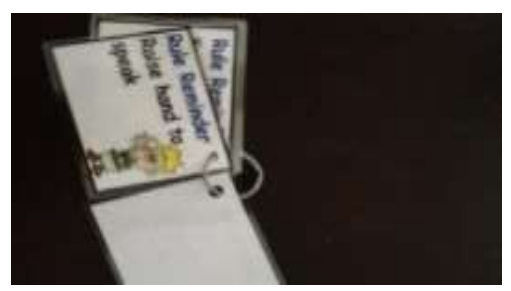

This type of media consists of a series of rules applied in the school. The teacher started by giving the instruction, prompting using the card and if the student could follow the instruction, a reward was then provided which could be verbal or by using a small reward. For example, the teacher said "now time for reading" and if the student do not react, then the teacher put media with that writing in front him to make him see it. The student usually follows the teacher's instructions which reflect his understanding.

\section{Media for discrimination training}

Besides DTT, other techniques were also implemented, such as: discrimination training. This technique was used in object identifications including identifying different colour, different shapes or different places and people.
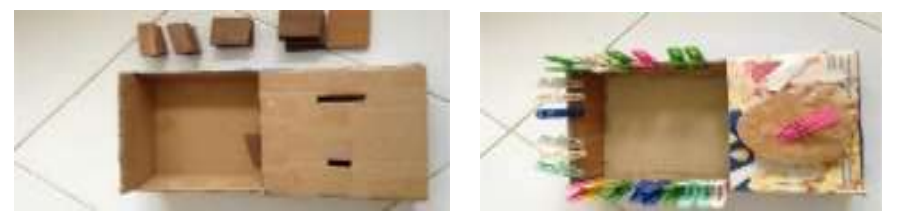

This type of media was used as a sorting task. The teacher asked "put the short block" and the student could put the block on the short hole. The objective was to differentiate which size for which slots, and which colours must be chosen and put in the hole when the teacher gave instructions. This is also considered as fine motor practice of eye-hand 
coordination, and also improves the student's understanding towards certain concepts. If the student can perform the activity correctly, the task can be extended by asking the student to do the activity and at the same time as verbalizing.

\section{Media for matching}

Matching is a technique for extending the identification training which is also intended to train students' precision in activities. This training is aimed at building the student's ability to identify the match shapes or to match things which have similar aspects.

\section{Media for fading technique}

This media can be in the forms of rules for the student which told him what can be done and what not to be done. This technique was utilized as a technique of slowly decreasing the dependency of the student and train the independency. The shadow teacher utilized the media as a means to visually show the concept and the student was then expected to internalize it through visual learning he was exposed to. The use of the media and its exposure was slowly decreased as soon as the understanding had been formed and built into a habit.

\section{Media for shaping}

This kind of media was used for training verbal expression given through a kind of drill. The purpose was to shape an understanding in the brain of the student and make it formed through repetition.
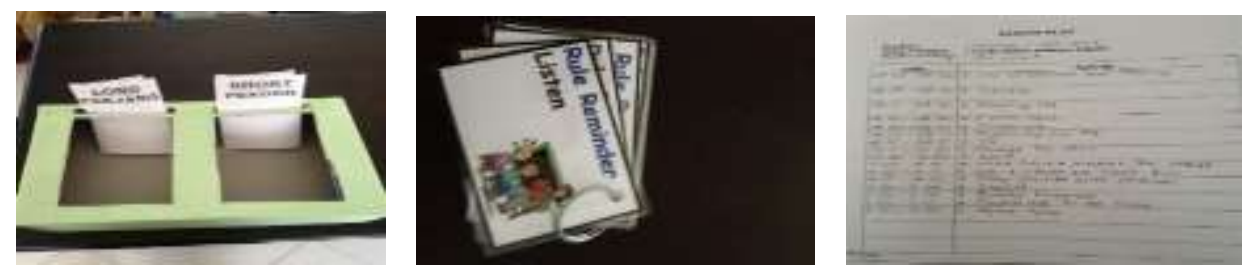

These media were used when the students were able to read. The first photo on the left side was used to train the student to differentiate the concept of 'short' and 'long' by separating things/objects based on their sizes. After that, the student was trained to say something about the objects. The photo in the middle was initially used for discrete trial training but the task could be extended by asking the student to talk about rules. The last photo on the right side is about a schedule of the activities done by the student in a day. This was shown to him in order to know his responsibility in a day. The teacher could extend the task by asking the student to communicate about his activities. The daily schedule is a terrific and potential recourse to help the student improve his ability to communicate about his life to other people, improve his vocabulary and language skills, can assist in developing time concepts, and can teach sequence, before and after. The schedule also provided an excellent structure to teach independent work habits. As the student masters the ability to transition from one activity to another by following the schedule, that procedure could be expanded to teach him to work for longer periods of time with less supervision. 
Media in the form of self-photos were also used in the IEP of the ASD student. The selfphoto media were usually used after some concepts on the receptive language had been understood by the student. The photo media were functioned as a scaffold for stimulating the student's memory about the events which acted as stimulus for creating responses. Besides introducing academic programs, the IEP also deals with introducing social functions. To improve the social function of the ASD student, modelling strategy was used in the form of a buddy program. The ASD student was paired with his peer, and imitated his peer in doing some things. In other words, his peer could give example by standing in front of the ASD student and showed him how to do things, or could be standing face-to-face when they needed to put on their uniforms. The buddy can be that who is fluent in English or can be those who can only talk in Bahasa Indonesia. The assignment was randomly conducted by the school. This buddy program was especially implemented in non-academic activities which aimed at improving the student's understanding and awareness about socializations with other people. Every week, the school gives different assignment for the students who acted as a buddy for the ASD student. Grouping students cooperatively in a buddy program is very essential not only giving a model for the ASD students but also giving other benefit. "Cooperative grouping provides opportunities for students to make connections with each other, thus lowering their affective filter and decreasing anxiety" (Almaguer \& Esquierdo, 2013).

The chosen strategies of implementing the media are directed and inspired by the S-R-r learning theory. In this theory, it is believed that the occurrence of behaviours is dependent on three crucial elements in learning: stimulus, which serves to elicit behaviour; a response triggered by a stimulus; and reinforcement, which serves to mark the response as being appropriate (or inappropriate) and encourage the repetition (or suppression) of response in the future (Richards and Rodgers, 2001). The implementation of the theory in practice seems to be successful as it is in line with the features of the ASD student who has deficits in social interactions and therefore frequently needs to be stimulated. The understanding is still mechanical. To shape the student's understanding about action verbs for example, the teacher used his own behaviour as a model. The teacher spoke out an activity and eventually performed the activity and let the student see it. Visually seeing the process allows the student to internalize the concept about the action stored in his brain.

Observing and analysing the ASD behaviours, some possible predictions and explanations can be drawn. The more frequent the image formed in his brain, the stronger the concepts formed. Therefore if it needs to be retrieved as stimulated by others for the social interaction purposes, the student might find it easier to retrieve the information which has been stored in his brain, because he just needs to retrieve it from his 'repertoire' memory in the brain. If the correct responses are performed, a reward is provided in order to give the chances that the good responses will be repeated again. However if there is no memory about a certain behaviour in his repertoire, it is less likely that he is able to retrieve that memory. Therefore, the environment around the student should be able to provide context which promotes incidental learning as well as intentional learning to take place. 


\section{The Techniques of Assessing and Identifying the Improvement of the Student}

The basic skills of reading and writing in the few years of elementary schools are very critical for the academic achievement throughout the school life (Ergül et.al, 2017), so assessment was also conducted on the skills of reading and writing. In order to measure the student's skills and the effectiveness of the strategies implemented by the teacher, assessments on language receptive skill were conducted. The summary of the result can be shown in the following table.

Table 1

Student's Language Receptive Skills

\begin{tabular}{|c|c|c|c|c|c|c|c|}
\hline \multirow{2}{*}{ Materials } & \multirow[t]{2}{*}{ Activities } & \multicolumn{6}{|c|}{ Months } \\
\hline & & 1 & 2 & 3 & 4 & 5 & 6 \\
\hline $\begin{array}{l}\text { Identifications of } \\
\text { feeling }\end{array}$ & $\begin{array}{l}\text { Identifying happy, sad, tired, } \\
\text { angry, feeling }\end{array}$ & $\sqrt{ }$ & + & $\sqrt{ }$ & ++ & $\sqrt{ }$ & + \\
\hline Identifying things & $\begin{array}{l}\text { Identifying colors, fruit, cloths, } \\
\text { anmals, places }\end{array}$ & $\sqrt{ }$ & $\sqrt{ }$ & $\begin{array}{l}+ \\
+\end{array}$ & ++ & + & ++ \\
\hline $\begin{array}{l}\text { Doing chain } \\
\text { activities }\end{array}$ & $\begin{array}{l}\text { Clapping - shaking hands, taking } \mathrm{n} \\
\text { giving, taking a pencil and writing }\end{array}$ & $\sqrt{ }$ & - & $\sqrt{ }$ & ++ & ++ & ++ \\
\hline $\begin{array}{l}\text { Identifying } \\
\text { Profession }\end{array}$ & $\begin{array}{l}\text { Policeman, post officer, fireman, a } \\
\text { teacher, farmer, doctor }\end{array}$ & - & $\sqrt{ }$ & - & - & $\sqrt{ }$ & $\sqrt{ }$ \\
\hline $\begin{array}{l}\text { Identifying certain } \\
\text { groups }\end{array}$ & $\begin{array}{l}\text { (vegetables, rice,meat,fruit, } \\
\text { animal, dols, transportatation) }\end{array}$ & $\sqrt{ }$ & $\sqrt{ }$ & $\begin{array}{l}+ \\
+\end{array}$ & ++ & + & + \\
\hline $\begin{array}{l}\text { Identifying } \\
\text { something }\end{array}$ & $\begin{array}{l}\text { Above, beside, in front of, behind, } \\
\text { outside, between }\end{array}$ & $\sqrt{ }$ & - & $\sqrt{ }$ & $\sqrt{ }$ & + & $\sqrt{ }$ \\
\hline $\begin{array}{l}\text { Responding to } \\
\text { questions }\end{array}$ & $\begin{array}{l}\text { Using what, who, how old... is } \\
\text { this.......? }\end{array}$ & $\sqrt{ }$ & $\sqrt{ }$ & $\begin{array}{l}+ \\
+\end{array}$ & ++ & + & ++ \\
\hline $\begin{array}{l}\text { Answering } \\
\text { questions 'yes/no' }\end{array}$ & Do you...? & + & + & $\sqrt{ }$ & ++ & ++ & ++ \\
\hline $\begin{array}{l}\text { Touching and } \\
\text { mentioning } \\
\text { something }\end{array}$ & $\begin{array}{l}\text { Touching......and saying..." "...." } \\
\text { (table, chair,pencil, book etc) }\end{array}$ & $\sqrt{ }$ & $\sqrt{ }$ & $\begin{array}{l}+ \\
+\end{array}$ & ++ & + & $\sqrt{ }$ \\
\hline
\end{tabular}

-: not willing to do the instruction, + : doing something without stimulation, $\sqrt{ }:$ doing something but without stimulation. ++ : doing something with own initiative

Table 1 indicates that the results of the assessment show that the student had been able to do tasks about identifying certain objects in English. He was also able to calculate basic mathematical questions like adding the number of objects. The amazing improvement was indicated when the shadow teacher asked him to read an English text, and surprisingly he could read the text very well. He was able to identify many expressions of feeling, to identify colours and places, able to do chain activities like clapping and shaking hands, able to identify kinds of profession, groups of things, and also to respond to simple questions. The student demonstrated competency in word recognitions and even excelling in the areas like phonics. In reading comprehension, which was checked through verbal interaction with the shadow teacher, it was not always evident yet that he understood the text. However, the progress was seen when the same English reading material was used again the following day. This is in line with 
other research findings (Nation at al.,2006, Newman, Macomb \& Naples, 2007; Finnegan and Mazin, 2015; Accardo, 2015) which stated that students with ASD may have strong decoding skills but still struggling with comprehension. Even though reading comprehension is stated as the ultimate goal of any reading activity (Hock \& Mellard, 2005, Ortlieb, 2013), it is likely that ASD student finds this very struggling. This phenomenon indicates that his understanding was rather mechanical and could be formed in the brain after the stimulus was repeatedly exposed to him. For that reason, more instruction in comprehensions needed to be designed for him. Comprehension instruction promotes active thinking skills and application of thinking processes (Browder at al., 2009; Accardo, 2015). The use of effective practices to teach comprehension to learners with ASD is crucial because literacy skills are critical for quality of life in areas such as community living, shopping, and following instructions (Carnahan, Williamson \& Haydon, 2009; Accardo, 2015). Despite the importance of comprehension in life, it seems that the student's comprehension about simple English reading text is still questionable and the social awareness is still low functioning, even though mechanically he was capable of reading it out in English.

\section{CONCLUSION}

From the discussion above it can be concluded that the tendency of ASD student to be visual learners has been accommodated by the decision of using visual media as the main media for instructions. The use of visual media in differentiated instruction in the form IEP has been observed to have important and beneficial impact on the motivation and success of the ASD student in learning English language. This impact was strengthened by the use of co-teaching strategy in inclusive classroom, visual support, and buddy program (for a model on how to behave and act especially in matters pertaining to non-academic activities). Presenting the message through visual supports or media helps the student establish and maintain attention. It also gives information in a form that the student can quickly repeat. The visual supports also clarify verbal information and provide a concrete way of internalizing concepts like time concept, sequence or cause/effect. The stability of the visual information allows the element of time necessary for the student to disengage, shift and re-engage attention. As a result, the student seems to understand better what he sees than what he hears and has visual interpretation skill that appear far superior to his auditory performance. Despite the ASD students is able to excel in word recognition and phonics, reading comprehension and socialization is still low functioning. This is likely the nature of being an individual with autistic spectrum disorder which will be carried over to his life. 


\section{REFERENCES}

American Psychiatric Association. (2013). Diagnostic and Statistical Manual of Mental Disorders (5th ed.). Arlington, VA: American Psychiatric Publishing.

Accardo, A.L. (2015). Research synthesis: Effective practices for improving the the reading comprehension of students with Autism Spectrum Disorder. DADD Online Journal, 2/1, 7-20. Retrived 30 January, 2017, from http://daddcec.org/Portals/0/CEC/Autism_Disabilities/Research/Publications/dec2_2015 \%20DOJ_2.pdf

Almaguer, I., \& Esquierdo J. J. (2013). Cultivating Bilingual Learners' Language Arts Knowledge: A Framework for Successful Teaching, International Journal of Instruction, 6/2, 3-18. Retrieved 6 January, 2017, from http://www.eiji.net/index.php?lang=en

Browder, D., Gibbs S., Ahlgrim-Delzell, L., Courtade, G. R., Mraz, M. \& Flowers, C. (2009). Literacy for learners with severe disabilities: What should we teach and what do we hope to achieve? Remedial and Special Education, 30, 269-282.

Cain, K., Oakhill, J., \& Bryant, P. (2004). Children's reading comprehension ability: Concurrent prediction by working memory, verbal ability, and component skills. Journal of Educational Psychology, 96, 31-42. doi:10.1037/0022-0663.96.1.31

Carnahan, C. R., Williamson, P. S., \& Haydon, T. (2009). Matching literacy profiles with instruction for learners on the spectrum: Making reading instruction meaningful. Beyond Behavior, 19, 10-16.

Choate, J. (1993). Special needs of special populations. In Successful muinstreaming: Proven ways to detect and correct special needs, in J. Choate (ed.). Needham Heights, Mass.: Allyn and Bacon.

Cummings, L. (2014). The Communication Disorders Workbook. Cambridge: Cambridge University Press.

Diaz, Z., W., M., Esquierdo, J.J., \& Ruiz-Escalante, J.A. (2013). Why did I ask that question? Bilingual/ESL pre-service teachers' insight. International Journal of Instruction, 6/2, 163-176, Retrieved January, 6 2017, from http://www.eiji.net/dosyalar/iji_2013_2_11.pdf

Duff, F. J., \& Clarke, P. J. (2015). Practitioner review: Reading disorders: What are the effective interventions and how should they be implemented and evaluated? Journal of Child Psychology \& Psychiatry, 52: 3-12. doi:10.1111/j.1469-7610.2010.02310.x

Ergül, C., Sarica, A.D., Akoglu, G., \& Karaman, G. (2017). The home literacy environments of Turkish kindergarteners: Does SES make a difference? International Journal of Instruction, 10(1), 187-202. Retrieved January 6, 2017, from http://www.eiji.net/index.php?lang=en 
Finnegan, E., \& Mazin, A.L. (2015). Teaching reading comprehension strategies to students with Autism Spectrum Disorders: Initial analysis of a surveyon current classroom practices, DADD Online Journal, 2(1), 157-171. Retrived 30 January, 2017, from http://daddcec.org/Portals/0/CEC/Autism_Disabilities/ Research/ Publications/dec2_2015\%20DOJ_2.pdf

Ford, J. (2013). Educating students with learning disabilities in inclusive classrooms, Electronic Journal for Inclusive Education, 3(1), Art. 2. http://corescholar.libraries. wright.edu/cgi/viewcontent.cgi?article=1154\&context=ejie

Frattura, E. M., \& Capper, C. A. (2007). Leading For Social Justice: Transforming Schools for All Learners. Thousand Oaks, CA: Corwin.

Gilhool, T. K. (1989). The right to an effective education: From Brown to P.L. 94-142 and beyond. In D. Lipsky \& A. Gartner (Eds.), Beyond separate education: Quality education for all (pp. 243-253). Baltimore: Paul H. Brookes.

Hodgdon, L. A. (2006). Visual Strategies For Improving Communication. Practical Support For School And Home. United States of America: QuirkRoberts Publishing.

Handojo, Y. (2009). Autisme pada Anak. Menyiapkan Anak Autis untuk Mandiri dan Masuk Sekolah Reguler dengan Metode ABA Basic. Jakarta: PT Buana Ilmu Populer.

Kalfus, G. R. (1984). Peer-mediated instruction: A critical review. Child Development and Family Behavior Therapy, 6, 17-43.

Liton, A.H. (2012). Developing EFL teaching and learning practices in Saudi colleges: A review. International Journal of Instruction, 5(2), 129-152.

Mayton, M. R., Wheeler, J. J., Menendez, A. L., \& Zhang, J. (2010). An analysis of evidence based practices in the education and treatment of learners with autism spectrum disorders. Education and Training in Autism and Developmental Disabilities, 45, 539-551.

McCorkle, S. L. (2012). Visual Strategies for Students with Autism Spectrum Disorders. Retrieved from: http://www.lynchburg.edu/wp-content/uploads/volume-62012/McCorkleS-Visual-Strategies-Students-ASD.pdf

Meynert, M. J. (2014). Inclusive education and perception of learning facilitators of children with special needs in a school in Sweden, International Journal of Special Education, 29(2), 35-47.

Nation, K., Clarke, P., Wright, B., \& Williams, C. (2006). Patterns of reading ability in children with autism spectrum disorder. Journal of Autism and Developmental Disorders 36, 911- 919. doi:10.1007/s10803-006-01301

Nordlund, M. (2003). Differentiated Instruction. Meeting the Educational Needs of All Students in Your Classroom. Oxford: The Scarecrow Press Inc. 
Noris B, Nadel J, Barker M, Hadjikhani N, \& Billard A. (2012). Investigating Gaze of Children with ASD in Naturalistic Settings. PLoS ONE 7(9), e44144. doi:10.1371/journal.pone.0044144

Ortlieb, E. (2013). Using anticipatory reading guides to improve elementary students' comprehension. International Journal of Instruction, 6(2), 145-162, Retrieved 6 January, 2017, from http://www.e-iji.net/index.php?lang=en

Padmadewi, N. N. (2013a). "Yes We Can”: Integrating a Special Need Student in a Bilingual Classroom (An article presented in CamTESOL Cambodia)

Padmadewi, N.N. (2013b). Differentiated instruction and task based learning: meeting the needs of heterogeneous students in a bilingual classroom, the new english teacher $7(1), 46-67$.

Pearson, J.N. (2015). Disparities in Diagnoses and Access to Services for African American children with Autism Spectrum Disorder, DADD Online Journal, 2(1), 52-65 Retrived 30 January, 2017, from http://daddcec.org/Portals/0/CEC/ Autism_Disabilities/ Research/Publications/dec2_2015\%20DOJ_2.pdf

Richards, J. C. \& Rodgers, T.S. (2001). Approaches and Methods in Language Teaching. Cambridge: Cambridge University Press.

Rutte, V. (2014) Integration models for elementary and secondary schools in Austria. Making It Happen. Example of Good Practice in Special Need Education \& Community-Based Programmes. United Nations Educational, Scientific and Cultural Organization (e-book downloaded on 12/6/2014 at 10.35)

Theoharries, G. (2009). The School Leaders Our Children Deserve: Seven Keys to Equity, Social Justice, and School Reform. New York, NY: Teachers College Press.

British Columbia Ministry of Education. (2000). Teaching Students with Autism: a Resource Guide for School. Victoria: Author.

Tomlinson, C. (1999). Differentiated classroom: Responding to the needs of all learners. Alexandria, VA: Association for Supervision and Curriculum Development.

Tomlinson, C. (2001). How to Differentiate Instruction In Mixed-Ability Classrooms (2nd ed.). Alexandria, VA: Association for Supervision and Curriculum Development.

Tuononen, K.J.S., Laitila, A., \& Kärnä, E. (2014). Context- Situated Communicative Competence in a Child with Autism Spectrum Disorder, International Journal of Special Education, 29(2), 4-17.

Wamalwa, E.J., \& Wamalwa, E.W. (2014). Toward the utilization of instructional media for effective teaching and learning of English in Kenya. Journal of Education and Practice, 5(31), 140-148.

Williamson, P., Carnahan, C. R., Birri, N. \& Swoboda, C. (2014). Improving comprehension of narrative using character event maps for high school students with 
autism spectrum disorder. The Journal of Special Education, Advance Online Publication, 1-11. doi:10.1177/0022466914521301

Vaughn, S., Schumm, J. S., \& Arguelles, M. E. (1997). The ABCDE's of co-teaching. Teaching Exceptional Children, 24, 67-74.

\section{Turkish Abstract \\ Endonezya'da Normal Bir Sınıfta Otistik Spektrum Bozukluğu Olan Bir Öğrenciye İngilizce Öğretmek}

Endonezya'da özel ihtiyaçları olan öğrencilerin sayısı son zamanlarda önemli ölçüde artmakta ve bu öğrencilere yönelik destekleyici okul programlarının yanı sıra daha iyi bir anlayışa acilen ihtiyaç duyulmaktadır. Endonezya'daki okulların ve öğretmenlerin öğrencilerin gerçek gereksinimlerini karşılamak için öğretim becerileri veya materyal geliştirme konularında hazırlıklarının sınırlı olduğu tespit edilmiştir. Bu çalışma, normal bir sınıfta Otistik Spektrum Bozukluğuna (ASD) sahip bir öğrenciye İngilizce öğretmenin uygun stratejilerini araştırmayı amaçlamıştır. $\mathrm{Bu}$ araştırma, North Bali Bilingual Okulu'nda durum çalışması biçiminde yapılmıştır. Araştırma verileri gözlem ve görüşmeler yoluyla toplanmıştır.

Anahtar Kelimeler: otistik spektrum bozukluğu, kapsayıcı okul, normal sınıf, özel ihtiyaçları olan öğrenciler, İngilizce öğretmek

\section{French Abstract \\ Enseignement d'anglais à un Étudiant avec Désordre de Spectre autistique dans Salle de classe Régulière en Indonésie}

La reconnaissance d'étudiants avec des besoins spéciaux a augmenté significativement en Indonésie récemment et la meilleure compréhension aussi bien que les programmes scolaires de soutien sont eus besoin en urgence. Il a été découvert que les écoles et les professeurs en Indonésie avaient très limité l'état de préparation en compétences enseignant ou le développement matériel pour répondre aux besoins réels des étudiants. Cette étude visant alors examinant les stratégies appropriées d'enseigner l'anglais à un étudiant avec des Troubles du spectre autistique (ASD) inclus dans une salle de classe régulière. Cette recherche était en forme d'une étude de cas conduite dans le Nord Bali l'École Bilingue. Les données ont été rassemblées par des observations et des entretiens.

Mots Clés: désordre de spectre autistique, école incluse, salle de classe régulière, étudiant avec besoins spéciaux, enseignant anglais 


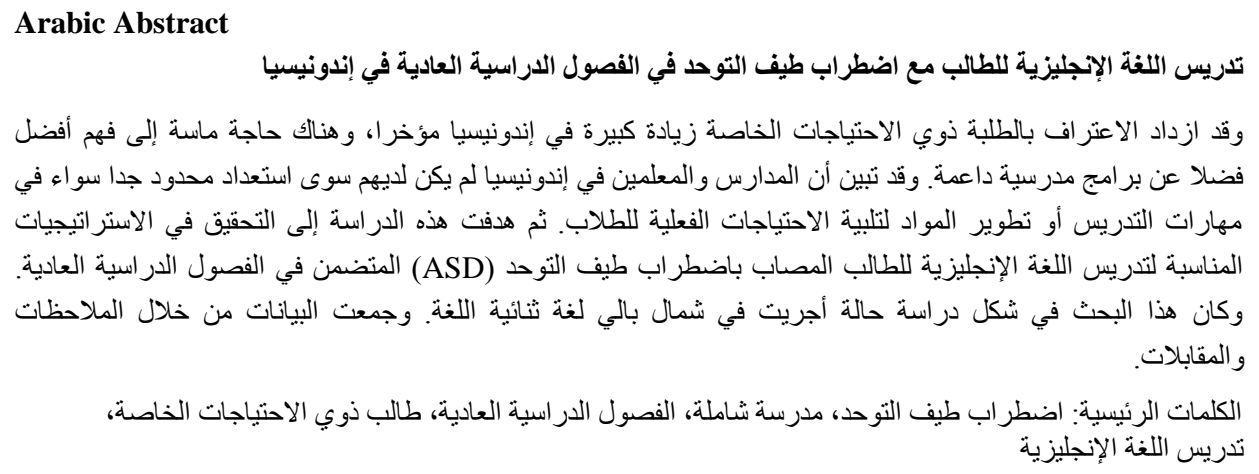

\section{German Abstract}

Unterricht Englisch zu einem Studenten mit Autismus-Spektrum-Störung im regelmäßigen Klassenzimmer in Indonesien

Die Anerkennung von Studierenden mit besonderen Bedürfnissen hat sich in Indonesien vor kurzem deutlich erhöht und das bessere Verständnis sowie unterstützende Schulprogramme sind dringend erforderlich. Es wurde herausgefunden, dass Schulen und Lehrer in Indonesien sehr begrenzte Vorbereitungen hatten, entweder in der Lehre Fähigkeiten oder materielle Entwicklung, um die tatsächlichen Bedürfnisse der Schüler zu erfüllen. Diese Studie zielte darauf ab, geeignete Strategien des Unterrichtens von Englisch an einen Schüler mit Autistic Spectrum Disorder (ASD) in einem regulären Klassenzimmer zu untersuchen. Diese Forschung wurde in Form einer Fallstudie in North Bali Bilingual School durchgeführt. Die Daten wurden durch Beobachtungen und Interviews gesammelt.

Schlüsselwörter: autismus-spektrum-störung, inkl. schule, reguläres klassenzimmer, student mit besonderen bedürfnissen, englischunterricht

\section{Malaysian Abstract \\ Pengajaran Bahasa Inggeris kepada Pelajar Autisme di Bilik Kelas Biasa di Indonesia}

Pengiktirafan murid berkeperluan khas telah meningkat dengan ketara di Indonesia baru-baru ini dan pemahaman yang lebih baik dan juga program-program sekolah sokongan diperlukan segera. Ia telah mendapati bahawa sekolah-sekolah dan guru-guru di Indonesia mempunyai persediaan yang sangat terhad sama ada dalam mengajar kemahiran atau pembangunan material untuk memenuhi keperluan sebenar pelajar. Kajian ini kemudian bertujuan untuk mengkaji strategi yang sesuai untuk mengajar bahasa Inggeris kepada pelajar dengan Autistic Spectrum Disorder (ASD) termasuk dalam kelas biasa. Kajian ini adalah dalam bentuk kajian kes dijalankan di North Bilingual School Bali. Data yang telah dikumpulkan melalui pemerhatian dan temu bual.

Kata Kunci: gangguan spektrum autisme, sekolah inklusif, kelas biasa, pelajar dengan keperluan khas, pengajaran Bahasa Inggeris 


\section{Russian Abstract}

Преподавание Английского Языка для Студентов с Расстройствами Аутистического Спектра в Обычных Классах в Индонезии

В последнее время в Индонезии значительно возросло количество учащихся с особыми потребностями. И возникла необходимость в лучшем понимании а также в поддерживающих школьных программах. Было выяснено, что школы и преподаватели в Индонезии имеют очень ограниченную подготовленность либо в области преподавания или развития материала для удовлетворения реальных потребностей учащихся. Это исследование затем было направлено на изучение соответствующих стратегий Чтобы Преподавать Английский Язык Студентам с Расстройствами Аутистического Спектра в Обычных Классах. Это исследование было представлено в форме тематического исследования, проведенного в двуязычной школе Северного Бали. Данные были собраны с помощью наблюдений и интервью.

Ключевые Слова: расстройство аутистического спектра, инклюзивная школа, обычный класс, учащийся со специальными потребностями, преподаватель английского языка 